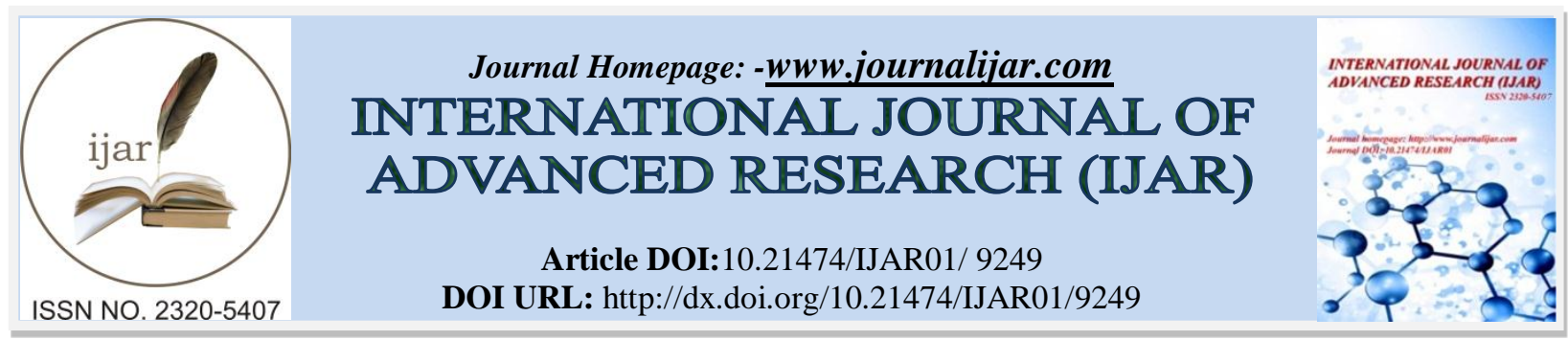

RESEARCH ARTICLE

\title{
INTELLECTUAL CAPITAL, CORPORATE PERFORMANCE AND CORPORATE GOVERNANCE AS MODERATING VARIABLE.
}

Ivon Cecilia Rompas, Victor Soeindra and Yanuar Dananjaya.

\section{Manuscript Info}

\section{Manuscript History}

Received: 10 April 2019

Final Accepted: 12 May 2019

Published: June 2019

Key words:-

Intellectual capital, Corporate

Governance, Size, Der, Corporate

Performance.

\begin{abstract}
Agency theory is a theory that explains the relationship between principal and agent in business. The main concern of this theory lies in how to solve problems that arise from agency relationships because of the inconsistency of objectives or differences in the assessment of a business risk. This problem can arise when the agent is motivated to take an action for his interests which is contrary to what he should have done or expected by the principal. This situation is commonly called moral hazard. Intellectual capital can reduce conflict because smart people may not necessarily increase the value of the company. But in reality high intellectual capital can cause high fraud and consequently make the company's performance not good. Therefore, corporate governance is needed to be able to report and monitor transparency carried out by intellectual capital and can reduce the occurrence of moral hazard.

This study aims to examine and analyze the influence of intellectual capital on corporate performance and to examine and analyze the effect of corporate governance on the relationship between intellectual capital and corporate performance. This research is a type of research with hypotheses, using quantitative approaches and secondary data taken from the Indonesia Stock Exchange. The population used in this study are companies listed on the Indonesia Stock Exchange (IDX) according to the criteria of the study sample.

The results showed that the intellectual capital variable with firm performance had a positive effect while the intellectual capital and corporate governance variables as moderating variables on firm performance had no effect. For size and der control variables there is a positive influence on company performance.
\end{abstract}

Copy Right, IJAR, 2019,. All rights reserved.

\section{Introduction:-}

Agency theory is a theory that explains the relationship between principal and agent in business. The main concern of this theory lies in how to solve problems that arise from agency relationships because of the inconsistency of objectives or differences in the assessment of a business risk. This problem can arise when the agent is motivated to take an action for his interests which is contrary to what he should have done or expected by the principal. This situation is commonly referred to as moral hazard. The occurrence of moral hazard can be caused by knowledge held by shareholders over others. Intellectual capital can reduce conflict because smart people may not necessarily 
increase the value of the company. But in reality high intellectual capital can cause high fraud and consequently make the company's performance not good. Therefore, corporate governance is needed to be able to report and monitor transparency carried out by intellectual capital and can reduce the occurrence of moral hazard.

Companies that still want to exist must make strategic decisions. Strategic decisions require competent human resources. Along with economic changes, which have knowledge-based characteristics with the application of knowledge management, the prosperity of a company will depend on the creation of transformation and capitalization of knowledge itself (Sawarjuwono, 2003). One that is considered important in maintaining competitive advantage and the value for the company, intellectual capital. Intellectual capital or intellectual capital (Petty and Guthrie, 2000) is one approach that is used to measure and assess knowledge assets. This resulted in intellectual capital becoming one of the important sources of wealth of the company because it contained important elements, namely science. But in reality, it turns out that a lot of intellectual capital in a company actually causes a lot of cheating. According to Abidin (2000) and Widyaningrum (2004), intellectual capital is still not widely known in Indonesia. Abidin (2000) also states that companies in Indonesia will be able to compete if they use the competitive advantage gained through creative innovations produced by the company's intellectual capital.

Parameters that are often used to assess the performance of a company are carried out using an approach where financial information is taken from financial statements. This requires them to look for more detailed information on matters relating to the management of intellectual capital, starting from the way of identifying, measuring, up to intellectual capital disclosure in the company's financial statements. Chen et al. (2005) conducted a study to examine the effect of intellectual capital on market value and financial performance of public companies in Taiwan. The results of the study show that intellectual capital has a positive influence on market value and corporate financial performance, and can be used as an indicator to assess the company's financial performance in the future. The research from Khalique et al. (2011) stated that intellectual capital greatly influences business performance, increases firm value, increases organizational effectiveness, competitive advantage, and also creates prosperity.

The application and management of good corporate governance or better known as good corporate governance is a concept that emphasizes the importance of the rights of shareholders to obtain information correctly, accurately and on time. The application of corporate governance is one of the right efforts applied by the company to increase intellectual capital performance. Safieddine et al. (2009) show that corporate governance and intellectual capital have strong links. This is very supportive in order to produce good performance in a company. The manufacturing companies are chosen by researchers to be the object of research. Because of the importance of intellectual capital in manufacturing companies, researchers are interested in conducting research in manufacturing companies.

Based on the description that has been explained, this study intends to reveal the effect of corporate governance on the relationship of intellectual capital and performance for companies.

\section{Literature Review \\ Intellectual Capital}

Intellectual capital is an important thing that can affect company performance. According to Bontis (1998) intellectual capital is a resource, ability and competence that drives organizational performance and corporate value creation. The indicator used to detect intellectual capital is Value Added Intellectual Coefficient (VAIC). In general, researchers have identified three main components of intellectual capital, namely: human capital (HC), structural capital (SC) and customer capital (CC).

\section{Corporate Governance}

Corporate Governance, or better known as Corporate Governance, is the relationship between the board of directors, top management, and shareholders in determining the direction and performance of the company. Good Corporate Governance is the principle that directs and controls the company in order to achieve a balance between the strength and authority of the company in giving its accountability. In Indonesia, Good Corporate Governance is defined as a pattern of relationships, systems, and processes used by companies (directors, board of commissioners, General Meeting of Shareholders (GMS) to provide added value to shareholders on an ongoing basis in the long term, while paying attention the interests of other stakeholders.

\section{Company performance}

Performance is an important thing that must be achieved by each company. Performance can be a benchmark for a company's ability to manage and allocate all its resources. Companies must continue to improve the quality and 
performance of the company so that the company's goals are achieved. Performance measures that are commonly used are measures of financial performance, while the notion of financial performance is the determination of certain measures that can measure the success of a company in generating profits (Sucipto, 2003). The measurement of company performance is proxied by return on assets (ROA) and return on equity (ROE).

\section{Size}

Company size is one factor in determining the level of investor confidence. According to Kustono (2009) the type of company size is divided into large companies, medium companies and small companies. Large companies are also assumed to have a fairly good performance and are able to generate profits compared to small companies. The greater the total assets, the greater the size of the company.

\section{Der (Debt to Equity Ratio)}

Der is an important tool in measuring the effectiveness of corporate debt usage. Der is a ratio that measures the proportion of funds sourced from debt to finance company assets (Sudana, 2009). The greater the ratio, shows the portion of debt usage in financing investments in assets is greater, which means also the company's financial risk increases and vice versa.

\section{Inter-Variable Relationships} Intellectual Capital Against Company Performance

In a study conducted by Sayyidah (2017), the results of Intellectual capital (VAIC TM) testing on firm value (Tobin's Q) have a positive effect. The results of the study stated that the company must have added value that would make the company superior to other companies. Fauzia (2016) states that intellectual capital has a positive effect on firm value. This means that the greater the intellectual capital allocated can increase the value of the company.

H1: Intellectual capital has a positive effect on company performance

\section{Intellectual Capital Against Company Performance With Corporate Governance as Moderation.}

Intellectual capital, supported by transparent management (corporate governance), will further enhance the value of the company. According to Juniarti (2013), Newell and Wilson (2002) state that corporate governance has a positive effect on firm value, because with the application of good corporate governance, it can reduce the risks that may be carried out by the board with decisions that benefit themselves, and generally corporate governance can increase the level of investor confidence. Good corporate governance will make a business entity be efficient, increase public trust, maintain the company's going concern, can measure the company's performance management targets, increase productivity, and reduce distortion.

$\mathrm{H} 2$ : Corporate governance strengthens the positive influence of intellectual capital on company performance.

\section{Size of Company Performance}

Research conducted by Primadanti and Eko (2013) states that there is a positive influence on firm size on return on assets (ROA). The results of the study show that financial companies have been optimally utilizing the size of the company in earning profits, the greater the size of the company they have, the more the company gets the maximum profit. According to Prasetyorini (2013) states that company size has a positive effect on firm value. Because the size of a large company indicates that the company is experiencing good growth.

\section{Der Against Company Performance}

The der ratio can describe how much the company's capital is financed by debt. If the company has high debt, it will improve the company's financial performance, whereas if the company has a low debt, it will reduce the company's financial performance (Fahmi, 2012). 


\section{Conceptual framework}

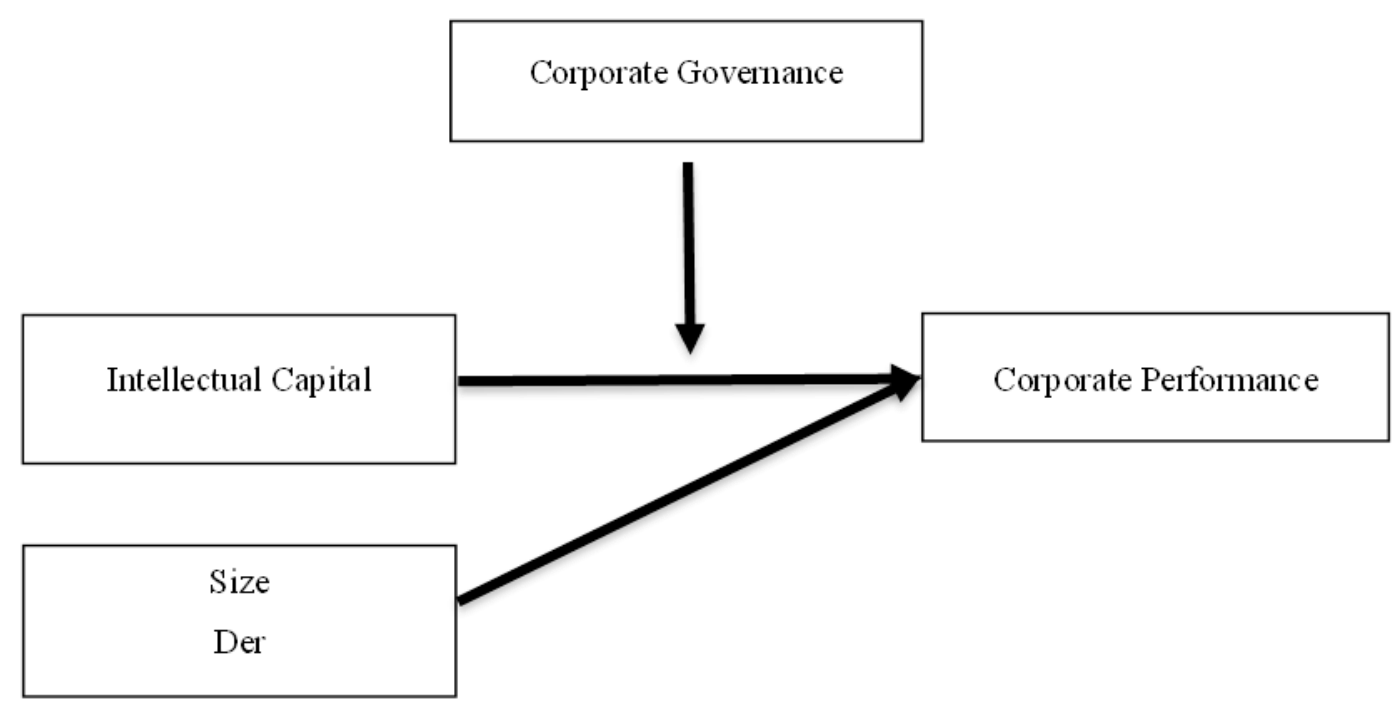

Picture 1:-Conceptual framework

\section{Research methods:-}

Research design

This research is a type of research with hypotheses, using a quantitative approach and secondary data taken from the Indonesia Stock Exchange which then the value is processed into input for research variables using statistical tools to produce a conclusion.

\section{Research Samples}

Samples or objects observed in the study are companies included in the category of manufacturing companies according to the criteria of the study from 2009-2016.

The sampling technique used in this study was purposive sampling technique. The company criteria determined for use in this study are as follows:

1. Companies listed on the Indonesia Stock Exchange during the research period, namely 2009-2016.

2. Companies that register themselves with SWA magazine for score scores Corporate Governance Perception Index (CGPI) from 2009-2016.

3. Companies that have information that is in accordance with their interests measurement of each variable in the study.

4. Companies that publish complete company data during research period.

\section{Analysis Method:-}

\section{Multiple Regression Analysis}

Regression tests were conducted to determine the relationship and influence between research variables. In this study, the data was processed using computer software namely EViews version 10 . The results of the regression analysis are in the form of coefficients for each independent variable. The multiple linear regression equations in this study are as follows:

$$
\mathrm{ROA}=\mathrm{C}(1)+\mathrm{C}(2) * \mathrm{IC}+\mathrm{C}(3) * \mathrm{IC} * \mathrm{CG}+\mathrm{C}(4) * \mathrm{SIZE}+\mathrm{C}(5) * \mathrm{DER}
$$

Information:

$\mathrm{C}=$ Konstanta

IC = Intellectual capital

$\mathrm{CG}=$ Corporate Governance

Size = Company Size

Der $=$ Debt 


\section{Classic assumption test}

Uji Multikolinearitas

Uji multikollinearitas bertujuan untuk menguji apakah model di dalam model regresi ditemukan adanya korelasi antara variabel independen.

Uji Autokorelasi

Uji autokorelasi bertujuan menguji apakah dalam model regresi linear ada korelasi antara kesalahan pengganggu pada periode t dengan kesalahan pengganggu pada periode t-1 (sebelumnya) (Ghozali, 2011).

Uji Heteroskedastisitas

Uji heteroskedastisitas bertujuan untuk menguji apakah di dalam model regresi terjadi ketidaksamaan variance dan residual satu pengamatan ke pengamatan yang lain.

\section{Results And Discussion:-}

Descriptive Statistics

The result of descriptive statistics is as follow

Tabel 1:-Descriptive Statistics

\begin{tabular}{|l|c|c|c|c|c|}
\hline VARIABLE & MINIMUM & MAXIMUM & MEAN & $\begin{array}{c}\text { STANDARD } \\
\text { DEVIASI }\end{array}$ & OBSERVATION \\
\hline ROA & 0,060 & 25,700 & 5,649 & 5,355 & 14 \\
\hline $\begin{array}{l}\text { Intellectual } \\
\text { Capital }\end{array}$ & 13,350 & 18,472 & 16,260 & 0,808 & 14 \\
\hline $\begin{array}{l}\text { Corporate } \\
\text { Governance }\end{array}$ & 69,000 & 89,000 & 80,326 & 4,865 & 14 \\
\hline Size & 14,400 & 17,974 & 16,196 & 0,772 & 14 \\
\hline Der & 0,110 & 22,200 & 1,667 & 3,196 & 14 \\
\hline
\end{tabular}

4.1 Classical Assumption Test

4.2.1 Multicollinearity Test

The result of Multicollinearity test is as follow

Tabel 2:-Multicollinearity Test

\begin{tabular}{|l|c|c|c|}
\hline VARIABLE & $\begin{array}{c}\text { COEFFICIENT } \\
\text { VARIANCE }\end{array}$ & UNCENTERED VIF & NANTERED VIF \\
\hline $\mathrm{C}$ & 178.0209 & 569.0315 & 3.2410 \\
\hline $\begin{array}{l}\text { Intellectual } \\
\text { Capital }\end{array}$ & 1.7342 & 1414.4060 & 3.2111 \\
\hline $\begin{array}{l}\text { Corporate } \\
\text { Governance }\end{array}$ & 0.0001 & 597.2893 & 1.4766 \\
\hline Size & 0.6862 & 561.8850 & 1.1981 \\
\hline Der & 0.0081 & 1.6923 & \\
\hline
\end{tabular}

\subsubsection{Autocorrelation Test}

The result of Autocorrelation Test is as follow

Tabel 3:-Autocorrelation Test

Breusch-Godfrey Serial Correlation LM Test:

\begin{tabular}{|l|l|l|l}
\hline F-statistic & 34.2356 & Prob. F(2.105) & 0.0000 \\
\hline Obs*R-squared & 44.2077 & Prob. Chi-Square(2) & 0.0000 \\
\hline
\end{tabular}

4.2.3 Heteroscedasticity Test

The result of Heteroscedasticity Test is as follow 
Tabel 4:-Heteroscedasticity Test

\begin{tabular}{|l|l|l|l|}
\hline \multicolumn{2}{|l|}{ Heteroskedasticity Test: White } & & \\
\hline F-statistic & 0.484910 & Prob. F(14,97) & 0.9362 \\
\hline Obs*R-squared & 7.325829 & Prob. Chi-Square (14) & 0.9214 \\
\hline Scaled explained SS & 17.13059 & Prob. Chi-Square (14) & 0.2493 \\
\hline
\end{tabular}

\subsubsection{Regression Test Analysis}

The result of Regression Test Analysis is as follow

Tabel 5:-Regression Test Analysis

\begin{tabular}{|c|c|c|c|c|}
\hline \multirow{2}{*}{\multicolumn{5}{|c|}{$\begin{array}{l}\text { Dependent Variable: ROA } \\
\text { Method: Least Squares (Gauss-Newton/Marquardt steps) }\end{array}$}} \\
\hline & & & & \\
\hline \multicolumn{5}{|c|}{\begin{tabular}{l|l} 
HAC standard errors \& & \\
covariance (Bartlett & \\
kernel, Newey-West fixed & \\
bandwidth $=5.0000)$ &
\end{tabular}} \\
\hline Variable & Coefficient & Std. Error & t-Statistic & Prob \\
\hline $\mathrm{C}$ & -52.7433 & 13.3425 & -3.9530 & 0.0001 \\
\hline Intellectual Capital & 2.9621 & 1.3169 & 2.2493 & 0.0265 \\
\hline $\begin{array}{l}\text { Intellectual } \\
\text { capital*corporate } \\
\text { governance }\end{array}$ & -0.0156 & 0.0106 & -1.4712 & 0.1442 \\
\hline Size & 1.8126 & 0.8283 & 2.1882 & 0.0308 \\
\hline Der & 0.7271 & 0.0903 & 8.0556 & 0.0000 \\
\hline
\end{tabular}

\begin{tabular}{|l|l|}
\hline R-squared & 0.3460 \\
\hline Adjusted R-squared & 0.3215 \\
\hline S.E of regression & 4.4112 \\
\hline Sum squared resid & 2082.0880 \\
\hline Log likelihood & -322.5883 \\
\hline F-statistic & 14.1511 \\
\hline Prob(F-statistic) & 0.0000 \\
\hline Prob(Wald F-statistic) & 0.0000 \\
\hline
\end{tabular}

\subsection{Test Hypothesis}

Tabel 6:-Test Hypothesis

\begin{tabular}{|l|c|c|c|c|c|}
\hline Variable & $\begin{array}{c}\text { Hypothesis } \\
\text { Research }\end{array}$ & Coefficient & t-Statistic & Prob & Research Result \\
\hline $\begin{array}{l}\text { Intellectual } \\
\text { Capital }\end{array}$ & + & 2,9621 & 2,2493 & 0,0265 & Positive Significant \\
\hline $\begin{array}{l}\text { Intellectual } \\
\begin{array}{l}\text { Capital*Corporate } \\
\text { Governance }\end{array}\end{array}$ & + & -0.0156 & -1.4712 & 0.1442 & Negative Not Significant \\
\hline
\end{tabular}

\section{Analysis And Discussion:-}

\subsection{Effect of Intellectual Capital on Company Performance}

Based on the results of the regression analysis that has been done, can be seen in the Table showing that the intellectual capital variable on the variable performance of the company has a positive effect. These results are in accordance with the formulation of the research hypothesis, namely intellectual capital has a positive effect on company performance. The results of this study are in accordance with the research conducted by

Gozali and Hatane (2014) state that intellectual capital has a positive effect on company performance, this is because investment in intellectual capital training is also an important investment and has economic value for the company so that it can increase company productivity. Companies need intellectual capital to achieve their goals where 
company success can be measured by company performance. Intellectual capital is one of the important factors of various aspects of a company's performance. This is very important because intellectual capital is one of the resources that aids development and development in the performance of the company.

According to Farahman and Khorasani (2013), the results of their research show that intellectual capital has a positive influence on company performance. According to Fathi et al. (2013), stating the fact that intellectual capital is an important asset strategy in competitive advantage which is characterized by company performance. This shows that managing intellectual capital effectively and efficiently can increase the value and performance of the company (Khan et al, 2012). According to Chen et al. (2005) show that intellectual capital has a positive effect on company performance, even intellectual capital can be one indicator to predict company performance in the future. In addition, the research conducted by Ulum (2007) proves that investors provide a different assessment on the research indicators, namely physical capital, human capital, and structural capital. This is in line with the research conducted by Puspitosari (2016) and Rini et al. (2016) about intellectual capital on company performance, which shows that there is a positive relationship between intellectual capital and company performance. Therefore, with good management of intellectual capital can create value added that is useful in improving company performance. Based on Resource Based Theory states that a company that is able to manage its resources and knowledge well then the company will have a competitive advantage that influences the company's performance (Belkaoui, 2003).

\section{The Effect of Intellectual Capital on Corporate Performance and Corporate Governance as a Moderating Variable}

From the results of regression analysis in Table 2, it shows that the results of research between intellectual capital variables on company performance and moderated by corporate governance variables are negative. That means that in this study corporate governance weakens the positive relationship between intellectual capital to company performance. The results of this study are also not in line with the formulation of the problem in the study.

In Indonesia there is a non-governmental organization which annually conducts good corporate governance practices, namely the Indonesian Institute for Corporate Governance (IICG). One form of activity carried out by IICG is the assessment of GCG implementation in Indonesia, known as CGPI (Corporate Governance Perception Index). The assessment conducted by CGPI consists of 13 components given to each company which will be rated at CGPI.

According to Johnson (2010), the weakness of corporate governance is often referred to as one of the causes of the financial crisis that occurred in Asian countries. Therefore, the application of good corporate governance is very much considered by investors in making investment decisions. Based on research conducted by Yasa and Susianti (2013) with a sample of 30 companies and 71 data observations, it shows that corporate governance has no effect on company performance. According to Ferial (2016) states that good corporate governance shows negative results on financial performance, because the more personnel who become board of commissioners can result in the worse performance of the company. This is because with the increasing number of members of the board of commissioners, they will experience difficulties in carrying out their roles, including difficulties in carrying out communication and coordination between board members.

Based on the results of the regression analysis conducted by Windah (2013), this shows that corporate governance cannot yet represent a tool to achieve or maximize the welfare of shareholders and stakeholders, especially in developing countries such as Indonesia. This research is in line with research conducted by Siahaan (2008) which shows that there is no relationship between corporate governance on company performance. The research conducted by Paradita (2009) states that corporate governance variables and company performance are negative. Research conducted by Daily et al. (1998) showed no relationship between corporate governance and company performance. The research above is in line with research conducted by Hidayah (2007) stating that the application of corporate governance does not directly affect performance. Company performance shows the company's ability to provide assets, equity, and debt benefits. According to Windah (2013), the research conducted shows that there is no influence between corporate governance variables on company performance.

Referring to the results of empirical research that has been done, although there are inconsistencies, the empirical evidence can show that the importance of the application of good corporate governance in supporting the achievement of corporate objectives and the basis of policy making so as to provide benefits to interested parties as a whole. 


\section{Conclusion And Recommendation:-}

Based on the results of research on "The Effect of Intellectual Capital on Corporate Performance with Corporate Governance as Moderation in Manufacturing Companies Listed on the Indonesia Stock Exchange in 2009-2016", the following conclusions were obtained:

1. There is a positive influence between the variable intellectual capital and company performance.

2. There is no influence between intellectual capital and corporate governance variables as moderating variables on company performance.

3. There is a positive influence between size as a control variable on company performance.

4. There is a positive influence between der as a control variable on company performance.

\section{Recommendation}

Based on the conclusions stated above, the suggestions put forward are:

1. For companies, they should always apply the principles of transparency and accountability so that they do not harm the public or other parties. Companies should always comply with the provisions in accordance with the principles of GCG.

2. For further researchers, it is expected to increase the number of research samples and years of research so that they can obtain good research result

\section{References:-}

1. Abidin. (2000). Sulitnya Mengkuantifikasi Modal Intelektual. Media Akuntansi, Oktober, 45-48.

2. Bontis, Nick (1998). "Intellectual Capital: An Exploratory Study that DevelopsMeasures and Models." Management Decision Vol. 36 No. 2, hal 63-76.

3. Chen, et al. (2005)." An empirical investigation of the relationship between intellectual capital and firms' market value and financial performance." Journal of Intellectual Capital Vol. 6 No. 2, hal. 159-176.

4. Fahmi, Irham. (2012). “Analisis Kinerja Keuangan”, cetakan ke-2 Bandung: Alfabeta

5. Fauzia, N., dan Amanah, L. (2016). Pengaruh intellectual capital, karakteristik perusahaan, dan corporate social responsibility terhadap nilai perusahaan. Jurnal Ilmu dan Riset Akuntansi, 5(4).

6. Ghozali, Imam (2011). "Aplikasi Analisis Multivariate Program IBM SPSS 19." Edisi 5. Badan Penerbit Universitas Diponegoro. Semarang.

7. Johnson, L. (2011). Law and legal theory in the history of corporate responsibility: corporate personhood. Seattle UL Rev., 35, 1135.

8. Juniarti, J. (2013). Good Corporate Governance and Predicting Financial Distress Using Logistic and Probit Regression Model. Jurnal Akuntansi Dan Keuangan, 15(1), 43-50.

9. Kustono, A. S. (2009). Pengaruh Ukuran, Deviden Payout, Risiko Spesifik, dan Pertumbuhan Perusahaan terhadap Praktik Perataan Laba pada Perusahaan Manufaktur Studi Empiris Bursa Efek Jakarta 20022006. Jurnal Ekonomi Bisnis, 14(3), 200-205.

10. Khalique, M., et al. (2011). Role of intellectual capital on the organizational performance of electrical and electronic SMEs in Pakistan.

11. Newell, R. and Wilson, G. (2002). Premium for Good Corporate Governance. The Mc Kinsey Quarterly.

12. Petty, et al. (2000). "Intellectual capital literature review: Measurement, reporting and management." Journal of Intellectual Capital Vol. 1 No. 2, hal. 155-76.

13. Prasetyanto, P. (2013). Pengaruh Struktur Kepemilikan dan Kinerja Intellectual Capital Terhadap Nilai Perusahaan. Skripsi. Universitas Diponegoro. Semarang.

14. Primadanti, D., \& Eko, U. P. (2013). Pengaruh Size, Leverage, dan Growth Terhadap Kinerja Perusahaan Pada Sektor Keuangan Yang Terdaftar di BEI Periode 2008-2011.

15. Safieddine, A., (2009), "Islamic Financial Institutions and Corporate Governance: New Insights for Agency Theory", Corporate Governance: An International Review, Vol 17, N², p.p. 142-158.

16. Sayyidah,U. (2017). "Pengaruh Intellectual Capital Terhadap Nilai Perusahaan Dengan Profitabilitas Sebagai Variabel Moderasi (Studi Pada Perusahaan Sub Sektor Property Dan Real Estate Di Bursa Efek Indonesia Periode 2013-2015). Vol 46, No. 1

17. Sawarjuwono, Tjiptohadi dan Agustine Prihatin Kadir (2003). "Intellectual Capital: Perlakuan, Pengukuran, dan Pelaporan (Sebuah Library Research).” Jurnal Akuntansi dan Keuangan. Vol. 5 No. 1, hal. 35-57.

18. Sucipto. (2003). Penilaian Kinerja Keuangan, FE Universitas Sumatera Utara.

19. Sudana, I Made. (2009). Manajemen Keuangan:Teori dan Praktek. Surabaya: Airlangga University Press.

20. Widiyaningrum, A. (2004). Modal intelektual. Jurnal Akuntansi dan Keuangan Indonesia, 1, 16-25. 
21. Windah, G. C., \& Andono, F. A. (2013). Pengaruh penerapan corporate governance terhadap kinerja keuangan perusahaan hasil survei the Indonesian Institute Perception Governance (IICG) periode 20082011. Calyptra, 2(1), 1-20. 